\title{
Maternal Mowing Effect on Seed Traits of an Invasive Weed, Erigeron annuus in Farmland
}

(Kesan Memotong Maternal ke atas Ciri Biji bagi Rumpai Invasif, Erigeron annuus di Ladang Ternakan)

\author{
Xiao-Hui Yong, JiAng-Hua Liu, Zhen Li, Shu-Feng Du, Zhuo-Wen Zhang, Xue-Feng Meng, \\ XIAO-JING WU \& YONG-JIAN WANG*
}

\begin{abstract}
The effect of maternal mowing on seed traits of an invasive weed, Erigeron annuus, in farmland was discussed by comparing mowing plants with intact (no-mowing) plants. The maternal mowing effect resulted in the decrease of seed mass, achene size, pappus length and germination percentage and the increase of variation in achene size, pappus length, dispersal distance and germination non-uniformity. To some extent, the individuals suffered mowing might accelerate the environmental adaptation through the increase of these variations. Our study indicated the mean of mowing in farmland will restrain the growth and reproduction of weed $\mathrm{E}$. annuus. However, it also increases the diversity of seeds through a more unequal provision to seeds that shares the risk and increases fitness to a wider range of heterogeneity of farmland condition.
\end{abstract}

Keywords: Achene size; Erigeron annuus; maternal mowing; seed traits

ABSTRAK

Kesan memotong maternal ke atas sifat biji bagi rumpai invasif, Erigeron annuus, di ladang ternakan telah dibincangkan dengan membandingkan tumbuhan yang dipotong dengan tumbuhan utuh (tidak dipotong). Kesan memotong maternal telah menyebabkan penurunan jisim biji, saiz aken, panjang papus, peratus percambahan serta peningkatan dalam variasi saiz aken, panjang papus, jarak penyebaran dan ketidak-seragaman percambahan. Sedikit sebanyak, individu yang mengalami kesan potongan mungkin cepat menyesuaikan diri dengan alam sekitar melalui peningkatan variasi ini. Kajian ini menunjukkan cara memotong di ladang ternakan akan menghalang pertumbuhan dan pembiakan rumpai E. annuus. Walau bagaimanapun, ia juga meningkatkan kepelbagaian biji melalui pembahagian tidak sama rata pada biji yang berkongsi risiko dan ia juga meningkatkan kecergasan julat untuk keheterogenan yang lebih luas dalam keadaan ladang ternakan.

Kata kunci: Erigeron annuus; memotong maternal; saiz aken; sifat biji

\section{INTRODUCTION}

Maternal environmental effect is the phenomenon that the phenotype of offspring not only depends on its own genotype and the environment it accounted but also depends on abiotic and biotic environment in which parents developed (Jason \& Michael 2009; Violle et al. 2009). The maternal mowing effect is one special type of maternal environmental effects. Many previous studies on mowing effect indicated that mowing reduced the production of biomass, flower and seed number of maternal plants (Simard \& Benoit 2011). However, few studies focused on the maternal mowing effect on seed traits such as mass, morphology, dispersal and germination, which have an important influence on the fitness of offspring and lineage (Meyer \& Carlson 2001; Violle et al. 2009).

$\mathrm{S}$ eed size or mass is very important for the fitness of offspring (Grime 1977). Differences in seed size are often associated with differences in embryo size. Many studies have shown that plants germinating from larger seeds have higher rate of survival (Rai \& Tripathi 1987; Venable et al. 1987), reproductive output (Beneke et al. 1993; Ellison 1987) and competitive advantages (Imbert et al. 1997; Rai \& Tripathi 1987) than plants derived from smaller seeds (Moles \& Westoby 2006; Westoby et al. 2002).

Seed dispersal is a strategy for increasing the range of experienced microenvironment by dispersing progeny in space, thus increasing the opportunity of encountering favorable establishment conditions. This opportunity is determined by both the spatial structure of environmental heterogeneity and dispersal distance (Jacobs \& Lesmeister 2012; Meyer \& Carlson 2001). If micro-environmental quality is varied within a habitat, a farther dispersal distance and a greater variance in dispersal distance could increase the probability of encountering a high-quality microsite to increase the fitness of offspring (Jacobs \& Lesmeister 2012). The dispersal distance of seed with a pappus is affected by seed morphology: The dispersal potential is assumed to increase with a higher ratio of length 
of pappus to the size of achene (Meyer \& Carlson 2001). So the relationship between achene size and pappus length is identified to make clear whether the seeds with a bigger achene will have a longer pappus. Many studies have documented the influence of dispersal distance on offspring fitness (Montesinos et al. 2006; Soons \& Heil 2002). However, studies about maternal environmental effects on mean seed dispersal distances and the variation of dispersal distances are rare (Donohue 1999). Furthermore, to the best of our knowledge, no previous work has examined the potential effect of maternal mowing on both mean dispersal distance and the variation of dispersal distances. Germination is an extremely important trait to the fitness of offspring (Geber \& Griffen 2003). Seed germination percentage is directly related with the number of offspring and greater percentage indicates a higher fitness of offspring and lineage. Additionally, a recent meta-analysis demonstrated that early emergence benefits offspring fitness because of early taking up the resources (Verdú \& Traveset 2005). However, synchronous germination is a high-risk strategy when the environment seeds encountered is very hostile and the spreading in germination time is a bet-hedging strategy to ensure there are always some seed germinating especially in the high variable and unpredictable habitats by increasing the scale of time (Gillespie 1977; Kaplan \& Cooper 1984). This bet-hedging strategy can also reduce sib competition (Cheplick 1996a, 1996b) and temporal variance in fitness. So far as we know, the maternal mowing effect on germination has not been studied.

Many invasive weeds, especially the species through seed dispersal, have highly damaged the species diversity in invaded habitats through competition and allelopathy. The worse is that its expanding ranges were rather fast. High quantity wind-dispersal seeds with a long dispersal distance and high rate of germination play an extremely important role during the invasion (Stratton 1989). The mowing activity is the regular way of weed control, we even have an acknowledgement that mowing can control the growth of maternal plants, we do not know whether the mowing can also restrain the fitness of offspring through affecting maternal plants.

This study was carried out to discuss whether maternal mowing effect can influence seed traits, whether there can be a trade-off between achene size and pappus length and whether the disadvantages of reducing the number of flower can be compensated by other advantages.

\section{MATERIALS AND METHODS}

\section{STUDY SPECIES}

Erigeron annuus is an invasive annual field weed from Canada. From June to September annually, the mature seeds can be dispersed everywhere by wind. Now it has been broadly distributed in farmlands, roadsides, forest edge and some other exposed habitat in China.

\section{STUDY SITES AND SAMPLING}

This study was performed in the farmland inside the campus of Huazhong Agricultural University, which is located in Wuhan $\left(113^{\circ} 41^{\prime}-115^{\circ} 05^{\prime} \mathrm{E}, 29^{\circ} 58^{\prime}-31^{\circ} 22^{\prime} \mathrm{N}\right)$, Central China. It has a typical subtropical humid monsoon climate with hot and rainy summer and cold winter. The annual average precipitation is $1140-1265 \mathrm{~mm}$, the annual average temperature is $16.6^{\circ} \mathrm{C}$ and annual average relative humidity is $77 \%$. E. annuus plants were collected from two neighboring farmland where the plant dominated the herb community. The mowing plants were collected from the farmland where mowing actions were carried out twice using lawn mower during spring (mid April and May 2012) (site A), while the intact (no-mowing) plants from another farmland without human disturbance (site B).

During mid-July 2012 when the seeds grown from the top inflorescence were completely mature, 30 individuals (distance $>1 \mathrm{~m}$ between individuals) were selected and marked respectively in sites A and B, and this finally yielded a total of 45 individuals (19 intact and 26 mowing individuals, seeds of part individuals were not collected due to the disturbances of wind and rainfall). Three to five flowers (capitula) of the top inflorescence of these individuals were kept in a paper bag for later seed measurement and the sampling was restricted to the top inflorescence to eliminate the effect of position of flower on the seeds (Buide 2008, 2004). Then, the rest of plants including roots were brought to the laboratory. All the capitula were separated and the number of capitula were recorded. Then all capitula (except the capitula used for seed measurement) and all the remaining parts of the plants were dried at $80^{\circ} \mathrm{C}$ for $72 \mathrm{~h}$ before being weighed.

\section{SEED MASS}

The capitula collected for measurement were air-dried at $25^{\circ} \mathrm{C}$ for $48 \mathrm{~h}$. 100 seeds as a group from each individual, totally 19 intact groups and 26 mowing groups, were weighed using a microgram precision balance to calculate mean seed mass, since the seeds were too tiny to be weighed one by one. Area and length of 20 seeds were measured to calculate the seed size and its coefficient of variation $(\mathrm{CV})$.

\section{DROP TIME OF SEEDS}

As the dispersal ability is related with the falling rate, we conducted an experiment to measure the time that it has taken for seeds to travel along a plastic tube (Fresnillo \& Ehlers 2008). The tube is $178 \mathrm{~cm}$ long and $50 \mathrm{~cm}$ wide, for it is extremely necessary to prevent horizontal air currents and provide a 'free air-current' work space (Fresnillo \& Ehlers 2008). The tube is longer than the one previously used to reduce the error caused by the human reaction time and it is wide enough to avoid the interference with wall during the falling process. The top of the tube was covered with a lid which had a hole in the middle to allow seed throwing. About 20 intact seeds with pappus of each 
individual were selected to drop, totally 375 seeds from intact individuals and 436 seeds from mowing individuals. Finally the mean value and $C V$ of drop falling rate (the length of tube /time) can be calculated.

\section{MORPHOLOGICAL TRAITS OF SEEDS}

Achene area and length of a total of 219 seeds from intact individuals and 252 seeds from mowing individuals were measured by Image-Pro Plus 6.0 (software). 5 pieces of pappus length in each seed (total 1904 seeds from intact plants and 1120 from mowing plants) were measured by Image-Pro Plus 6.0 software. Morphological measurement has two intentions: To calculate the mean value and $C V$ of achene size using the achene area and length and to identify their relationships.

\section{SEED GERMINATION}

The capitula collected for germination tests were air-dried at $25^{\circ} \mathrm{C}$ for $72 \mathrm{~h}$ and then stored at $5^{\circ} \mathrm{C}$ until October 2012 . 50 seeds of each individual were treated as a group, in total 19 groups from intact individuals and 25 groups from mowing individuals were set to germinate in Petri dishes in germinative incubators $\left(20^{\circ} \mathrm{C}, 12 \mathrm{~h}\right.$ day/12 h night $)$. Germination was recorded as soon as the radicle emerged and then germinated seeds were removed from the Petri dishes. The survey was performed at 8 p.m. every day for 36 days until a mould infection interfered with germination. The total number of seeds germinated throughout the experiment was recorded to calculate the germination percentage of each plant as the ratio between germinated seeds and the initial number of seeds. The distribution of number of germinated seeds on each day was recorded to calculate the germination rate and germination uniformity. The germination rate is calculated through this expression of coefficient of velocity presented by Kotowski (1926):

$$
\begin{aligned}
\text { germination rate }= & 100\left(A_{1}+A_{2}+\ldots+A_{x}\right) / \\
& \left(A_{1} T_{1}+A_{2} T_{2}+\ldots+A_{x} T_{x}\right),
\end{aligned}
$$

where $A_{1}, A_{2}, \ldots, A_{x}$ is the number of seedlings counted on the first day, second day until the last day $(x)$; and $T_{1}, T_{2}, \ldots, T_{x}$ is the number of days between sowing and the first collection, between the sowing and the second collection until the last collection $(x)$. The coefficient of non-uniformity of germination measures the variability (the spreading in germination time) of germination time among seeds was calculated as:

$$
C V_{t}=\left(S_{t} / \bar{t}\right) \times 100,
$$

where

$$
\begin{aligned}
& \bar{t}=\left(G_{1} T_{1}+G_{2} T_{2}+\ldots+G_{n}\left(T_{n}\right) /\left(G_{1}+G_{2}+\ldots+G_{n}\right)\right. \\
& s_{t}=\sqrt{s_{t}^{2}}
\end{aligned}
$$

and

$$
s_{t}^{2}=\sum_{i=1}^{n} G_{i}\left(T_{i}-\bar{t}\right)^{2} /\left(\sum_{i=1}^{n} G_{i}-1\right),
$$

where $G$ is the number of seeds germinated in time $I ; n$ is the last time of germination; $T_{i}$ is the time between the start of the experiment; and $i^{\text {th }}$ is the observation (Dorneles et al. 2005).

\section{DATA ANALYSIS}

Normality was tested before following the analysis using non-parametric KS test and all data were normal distributed except flower number, pappus length, achene area and achene length. Independent sample $t$ test $(t)$ was used to assess the maternal mowing effect on the growth and reproduction of plants (except flower number) and traits of seeds (except pappus length, achene area and achene length). Two independent sample nonparametric test $(z)$ were used to test the difference of flower number, mean value and $C V$ of pappus length, achene area and achene length between intact and mowing plants. Spearman correlation was used to assess the relationship between achene size and pappus length. All statistic analysis was carried out by SPSS 17.0 software (SPSS, Chicago, IL, USA). Figures were drawn by Origin 7.0 software.

\section{RESULTS}

\section{THE MOWING EFFECT ON THE GROWTH OF E. ANNUUS}

A significant mowing effect on total biomass, biomass of flowers, number of flowers and height of plants was observed. The individuals exposed to mowing treatment showed significantly lower total biomass, flower mass, number of flowers and height. However, the allocation to flowers (flower biomass/total biomass) did not show any significant difference between intact and mowing plants (Table 1).

\section{THE MOWING EFFECT ON MASS AND MORPHOLOGY OF SEEDS}

The mean value of thousand seed mass and seed morphology were affected by mowing treatment. Seed mass of mowed individuals were significantly lower than that of intact individuals. The mowed individuals had significantly smaller seeds than intact individuals. Pappus length of seeds from mowed individuals was also significantly smaller than intact individuals (Figure 1). The $C V$ of seed area of mowed individuals was significantly higher than intact individuals. Additionally, a marginally non-significant trend for maternal mowing effect on $C V$ of seed length and pappus length was observed, which of mowed individuals were marginally higher than that of intact individuals (Figure 2). Significantly positive 
TABLE 1. Growth traits (Mean \pm SE) for mowing and intact plants

\begin{tabular}{lcccc}
\hline & Mowing $(n=26)$ & Intact $(n=19)$ & Test & $P$ \\
\hline Height $(\mathrm{cm})$ & $40.14 \pm 2.05$ & $101.52 \pm 12.24$ & $t_{(8)}=-4.95$ & $<0.001$ \\
Total biomass $(\mathrm{g})$ & $1.64 \pm 0.04$ & $31.04 \pm 8.86$ & $t_{(43)}=3.90$ & $<0.001$ \\
Biomass of flower $(\mathrm{g})$ & $0.27 \pm 0.01$ & $5.18 \pm 1.50$ & $t_{(43)}=3.86$ & $<0.001$ \\
Allocation to flower $(\%)$ & $16.81 \pm 0.70$ & $18.00 \pm 1.16$ & $t_{(43)}=0.91$ & 0.366 \\
Number of flowers & $34.62 \pm 0.64$ & $707.26 \pm 178.89$ & $z=3.313$ & $<0.001$ \\
\hline
\end{tabular}

Notes: $n$ was 5 for height in both treatments, $d$.f. was 8 for height, and 43 for other parameters. $t$ was independent sample $t$ test and $\mathrm{z}$ was independent sample nonparametric test, which were the same below
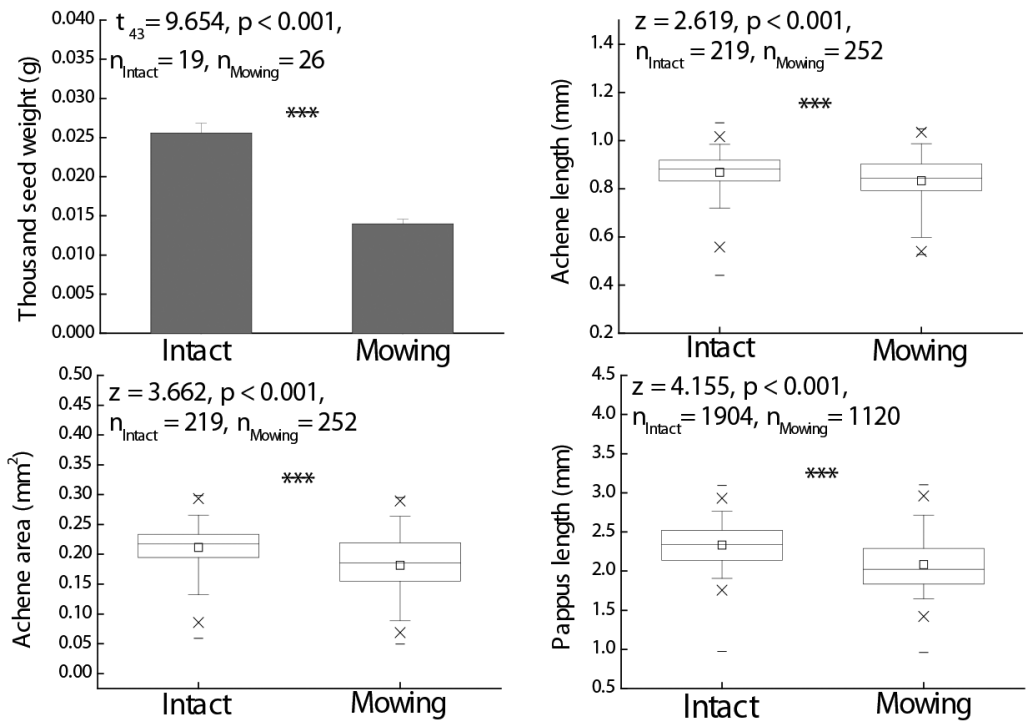

FIGURE 1. The mowing effect on seed mass and seed morphology (Mean $\pm \mathrm{SE}$ ). $n s$ indicates no significant difference at $p=0.05, * 0.01 \leq p<0.05, * * 0.001 \leq p<0.01$ and $* * * p<0.001$
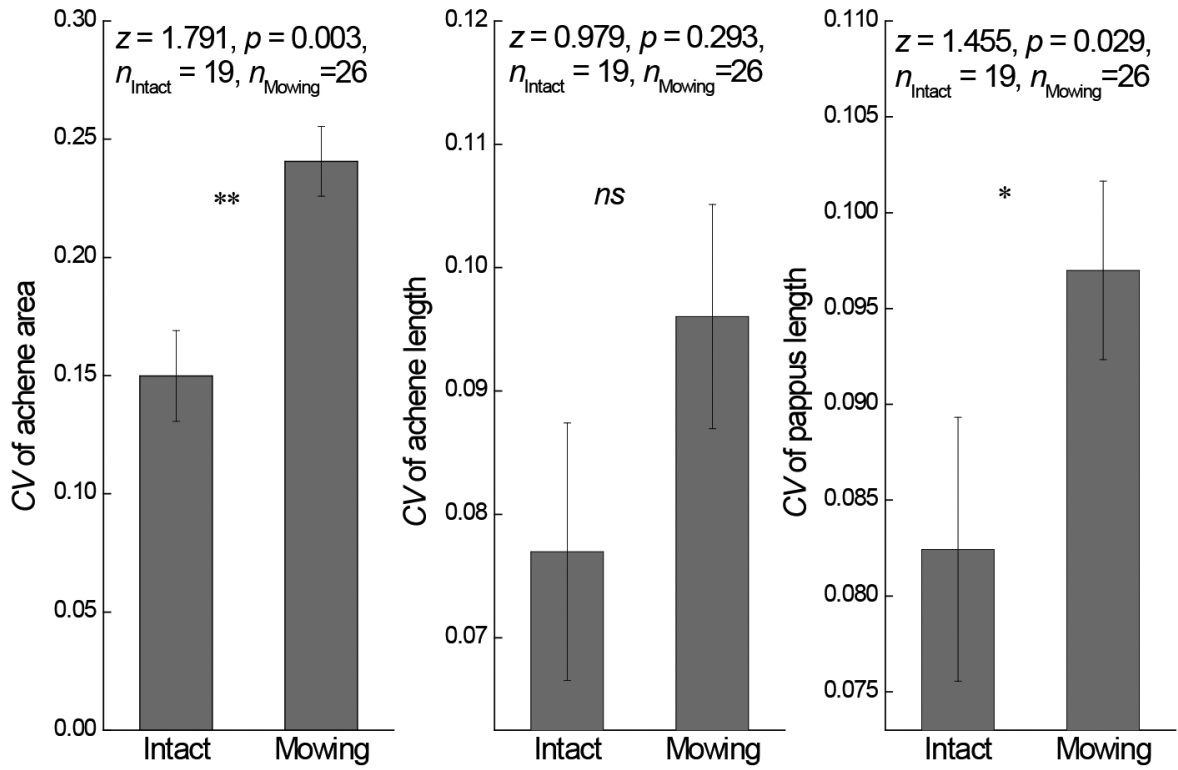

FIGURE 2. The mowing effect on coefficient of variation (CV) of seed morphology (Mean \pm SE). $n s$ indicates no significant difference at $p=0.05, * 0.01 \leq p<0.05, * * 0.001 \leq p<0.01$ and $* * * p<0.001$ 
relationship between achene area and pappus length $\left(R^{2}\right.$ $=0.160, n=472, p<0.001)$ and between achene length and pappus length $\left(R^{2}=0.255, n=472, p<0.001\right)$ were observed (Table 2).

\section{THE MOWING EFFECT ON FALLING SPEED AND CV OF FALLING SPEED}

There was no significant maternal mowing effect on falling speed (Figure 3). The average falling speed of seeds was about $30 \mathrm{~cm}$ per second. But the results showed that $C V$ of falling speed of seeds from mowed individuals was significantly higher than that of intact individuals (Figure 3).

\section{THE MOWING EFFECT ON SEED GERMINATION OF E. ANNUUS}

A significant mowing effect on germination percentage and germination non-uniformity was observed, but germination rate did not respond to mowing effect (Figure 4). The germination percentage of seeds of mowed individuals were significantly lower than that of intact individuals, but $\mathrm{CV}$ of germination time of seeds from mowed individuals was significantly higher than that of intact individuals (Figure 4).

\section{DISCUSSION}

In this experiment, a strong mowing effect on growth and reproduction of maternal plants was utilized, which allowed us to test the response of the seed traits of $E$. annuus to maternal mowing effect in order to compensate the restrain of growth. Our results showed that the growth of plants, the flower number and biomass, plant biomass and plant height were all seriously restrained by mowing. Seed was considered as a cornerstone trait to explain maternal effects (Weiner et al. 1997). In this study, mean seed mass and mean seed size were strongly reduced by mowing, while the variance of seed size was significantly increased. The mass and morphology of seeds can affect the dispersal potential. The larger winddispersed seeds fall faster and achieve smaller dispersal distances. However, if the length of pappus increases with the increasing achene size, the case will be different. A previous study on Ericameria nauseosus indicated the relative investment on pappus did not show a consistent increase with achene mass (Meyer \& Carlson 2001), but our result demonstrated a significantly positive relationship between achene area and pappus length. This trend explained why the falling speed of seeds did not show a difference between intact and mowing individuals. The

TABLE 2. Spearman correlation coefficient between pappus length and achene size (achene area and achene length)

\begin{tabular}{lcccccc}
\hline & & Achene area & \multicolumn{3}{c}{ Achene length } \\
& $R^{2}$ & $p$ & $n$ & $R^{2}$ & $p$ & $n$ \\
\hline Pappus length & 0.160 & $<0.001$ & 472 & 0.255 & $<0.001$ & 472 \\
\hline
\end{tabular}
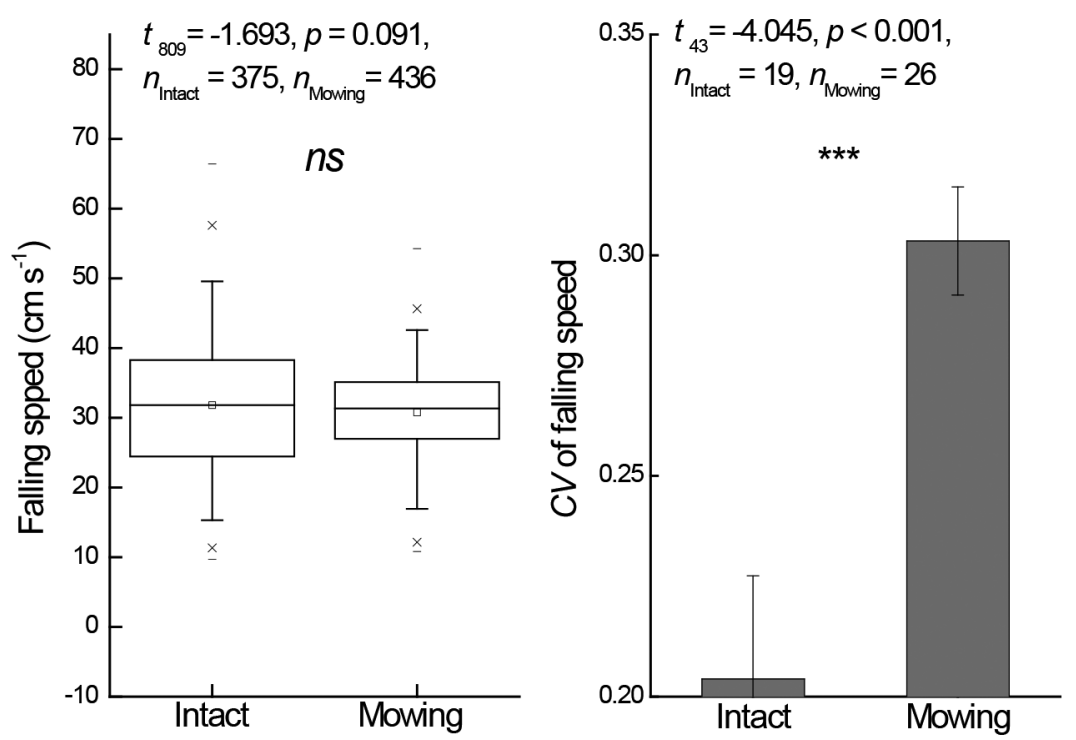

FIGURE 3 . The mowing effect on mean falling speed and coefficient of variation $(C V)$ of falling speed of seeds (Mean $\pm \mathrm{SE}$ ). $n s$ indicates no significant difference at $p=0.05$, * $0.01 \leq p<0.05, * * 0.001 \leq p<0.01$ and $* * * p<0.001$ 




FIGURE 4. The mowing effect on germination percentage, germination rate and germination nonuniformity (Mean $\pm \mathrm{SE}$ ). $n s$ indicates no significant difference at $p=0.05$, $* 0.01 \leq P<0.05, * * 0.001 \leq p<0.01$ and $* * * p<0.001$

novel of our study was to show whether mowing increase the variance of achene size and pappus length withinindividually, this higher variance of mowing plants in this study may in some extent explain why $C V$ of falling speed of seeds from mowing plants was significantly higher than seeds from intact seeds. Combined, the results suggested that maternal mowing effect on dispersal distance may be positive and the increased variance in dispersal distance could increase the heterogeneity in environmental quality encountered by offspring, thus increasing the probability of encountering high-quality habitat (Baythavong 2011). These results indicated the plants could not be able to dispersal their seeds farther after imposed to stress, but they could dispersal their seeds in more variable distance if there are some seeds falling on the high-quality habitat. This increasing variance in dispersal distance will absolutely increase the fitness of offspring. However, in order to test the fitness of offspring in heterogeneous environment, further field experiments are needed.

Seed mass and morphology not only influence dispersal potential but also influence the germination. Seeds from mowing individuals have a lower germination percentage, the same germination rate and a higher variance in germination time, which can be explained by changes in mean seed mass and variance of seed size. Many previous studies demonstrated lighter seeds often germinate more slowly (Mogie et al. 1990; Tavsanoglu \& Catav 2012) and in lower numbers (Stanton 1985) than heavier seeds, because the larger seeds from intact individuals are better-provisioned. Therefore, it has a higher chance to germinate and it is germinated faster (Violle et al. 2009) than smaller seeds from mowing individuals (Jacobs \& Lesmeister 2012). In terms of this, larger seeds from intact plants will lead a higher germination percentage and higher germination rate and the higher variance of seed size leads a greater non-uniformity of germination. However, germination rate did not response to changes in mean seed mass, which may also be related with some other traits of seed such as the existence of pappus. A recent study indicated that achene, which acts as a conduit facilitating water entry into the seed, with more pappi germinated faster than that with less pappi (Hale et al. 2010). Definitely a decline in germination percentage after mowing is a negative response to maternal mowing effect by decreasing the number of offspring. However, the increase of variance in germination time is a positive response, which will increase the chance of avoiding a hostile environment such as high or low temperature, too much or too less water and encountering a high-quality environment (Wang et al. 2013, 2012). Finally, this higher non-uniformity will increase the fitness of offspring by increasing the range of future environmental conditions in time scale (Wang et al. 2009).

Furthermore, the effect of maternal environment can persist into a third generation (Case et al. 1996) and this effect may also be mediated through seed weight. The seedlings derived from lighter seeds might grow more slowly (Stanton 1984) and achieve a lower biomass (Zhang \& Maun 1990), tend not to flower or produce fewer flowers, and set fewer fruits or seeds (Mazer 1987) than those derived from heavier seeds. Therefore, we need to track the maternal mowing effect on the fitness of the following generations through field-planting experiment of seeds by several generations in future. 


\section{CONCLUSION}

The maternal mowing effect brings disadvantages to the fitness of maternal plants and offspring. However, it increased the variation in achene size, pappus length, disperse distance and germination non-uniformity. These variations might lead the seeds to adapt a wider range of heterogeneity in space and time, which could increase risk-spreading and survival rate. Our study indicated the mean of mowing in farmland will restrain the growth and reproduction of weed E. annuus. However, it also increases the diversity of seeds through a more unequal provision to seeds that shares the risk and increases fitness to a wider range of heterogeneity of farmland condition. This study may suffer the influences of other factors (in term of soil context) due to being partly conducted in the field and therefore further research in greenhouse will be carried on.

\section{ACKNOWLEDGMENTS}

We thank Kai-Li Liu, Yu Cao, Fu-Lin Ding, Ye Xiang and Yang Li for their assistance in the fieldwork. This study was supported by the National Natural Science Foundation of China (No. 31000194, 31270465).

\section{REFERENCES}

Baythavong, B.S. 2011.Linking the spatial scale of environmental variation and the evolution of phenotypic plasticity: Selection favors adaptive plasticity in fine grained environments. The American Naturalist 178: 75-87.

Beneke, K., van Rooyen, M.W., Theron. G.K. \& van de Venter, H.A. 1993. Fruit polymorphism in ephemeral species of Naquamaland. IV. Growth analyses of plant cultivated from the dimorphic diaspores. Journal of Arid Environments 24: 345-360

Buide, M.L. 2008. Disentangling the causes of intra-inflorescence variation in floral traits and fecundity in the hermaphrodite Silene acutifolia. American Journal of Botany 95: 490-497.

Buide, M.L. 2004. Intra-inflorescence variation in floral traits and reproductive success of the hermaphrodite Silene acutifolia . Annals of Botany 94: 441-448.

Case, A.L., Lacey, E.P. \& Hopkins, R.G. 1996. Parental effects in Plantago lanceolata L. II. manipulation of grandparental temperature and parental flowering time. Heredity 76: $287-$ 295.

Cheplick, G.P. 1996a. Do seed germination patterns in cleistogamous annual reduce the risk of sibling competition? Journal of Ecology 84: 247-255.

Cheplick, G.P. 1996b. Cleistogamy and seed heteromorphism in Triplasis purpurea (Poaceae). Bulletin of the Torrey Botanical Club 123: 25-33.

Donohue, K. 1999. Seed dispersal as a maternally influenced character: Mechanistic basis of maternal effects and selection on maternal characters in an annual plant. The American Naturalist 154: 674-689.

Dorneles, M.C., Ranal, M.A. \& Santana, D.G. 2005. Germinação de diásporos de Myracrodruon urundeuva Allemão (Anacardiaceae) ocorrente no cerrado do Brasil Central [Germination of newly collected diaspores of Myracrodruon urundeuva Allemão (Anacardiaceae) occurring in the cerrado of Central Brazil]. Revista Brasileira de Botânica 28: 399408. (In Finnish with English summary).

Ellison, A.M. 1987. Effect of seed dimorphism on the density dependent dynamics of experimental populations of Atriplex triangularis (Chenopodiaceae). American Journal of Botany 74: 1280-1288.

Fresnillo, B. \& Ehlers, B.K. 2008. Variation in dispersability among mainland and island populations of three wind dispersed plant species. Plant Systematics and Evolution 270: 243-255.

Geber, M.A. \& Griffen, L.R. 2003. Inheritance and natural selection on functional traits. International Journal of Plant Sciences 164: 21-42.

Gillespie, J.H. 1977. Natural selection for variances in offspring numbers, a new evolutionary principle. The American Naturalist 111: 1010-1014.

Grime, J.P. 1977. Evidence for the existence of three primary strategies in plants and its relevance to ecological and evolutionary theory. The American Naturalist 111: 11691194.

Hale, A.N., Imfeld, S.M., Hart, C.E., Gribbins, K.M., Yoder, J.A. \& Collie, M.H. 2010. Reduced seed germination after pappus removal in the North American dandelion (Taraxacum officinale; Asteraceae). Weed Science 58: 420-425.

Imbert, E., Escarré, J. \& Lepart, J. 1997. Seed heteromorphism in Crepis sancta (Asteraceae), performance of two morphs in different environments. Oikos 79: 325-332.

Jacobs, B.S. \& Lesmeister, S.A. 2012. Maternal environmental effects on fitness, fruit morphology and ballistic seed dispersal distance in an annual forb. Functional Ecology 26: 588-597.

Jason, B.W. \& Michael, J.W. 2009. What are maternal effects (and what are they not)? Philosophical Transactions of the Royal Society of London Series B-Biological Sciences 364: 1107-1115.

Kaplan, R.H. \& Cooper, W.S. 1984. The evolution of developmental plasticity in reproduction characteristics, an application of the 'adaptive coin-flipping' principle. The American Naturalist 123: 393-410.

Kotowski, F. 1926. Temperature relations to germination of vegetable seed. Proceedings of the American Society for Horticultural Science 23: 176-184.

Mazer, S. 1987. Parental effects on seed development and seed yield in Raphanus raphanistrum: Implications for natural and sexual selection. Evolution 41: 35-371.

Meyer, S.E. \& Carlson, S.L. 2001. Achene mass variation in Ericameria nauseosus (Asteraceae) in relation to dispersal ability and seedling fitness. Functional Ecology 15: 274-281.

Mogie, M., Latham, J.R. \& Warman, E.A. 1990. Genotypeindependent aspects of seed ecology in Taraxacum. Oikos 59: 175-182.

Moles, A.T. \& Westoby, M. 2006. Seed size and plant strategy across the whole life cycle. Oikos 113: 91-105.

Montesinos, D., Garcia-Fayos, P. \& Mateu, I. 2006. Conflicting selective forces underlying seed dispersal in the endangered plant Silene diclinis. International Journal of Plant Sciences 167: 103-110.

Rai, J.P.N. \& Tripathi, R.S. 1987. Germination and plant survival and growth of Galingosa parviflora Cav. as related to food and energy content of its ray- and disc-achenes. Acta Oecologica 8: 155-165.

Simard, M.J. \& Benoit, D.L. 2011. Effect of repetitive mowing on common ragweed (Ambrosia Artemisiifolia L.) pollen and 
seed production. Annals of Agricultural and Environmental Medicine 18: 55-62.

Soons, M.B. \& Heil, G.W. 2002. Reduced colonization capacity in fragmented populations of wind-dispersed grassland forbs. Journal of Ecology 90: 1033-1043.

Stanton, M. 1984. Seed variation in wild radish: Effect of seed size on components of seedling and adult fitness. Ecology 65: 1105-1112.

Stanton, M. 1985. Seed size and emergence time within a stand of wild radish (Raphanus raphanistrum L.): The establishment of a fitness hierarchy. Oecologia 67: 524-531.

Stratton, D.A. 1989. Competition prolongs expression of maternal effects in seedlings of Erigeron annuus (Asteraceae). American Journal of Botany 76: 1646-1653.

Tavsanoglu, C. \& Catav, S.S. 2012. Seed size explains withinpopulation variability in post-fire germination of Cistus salviifolius. Annales Botanici Fennici 49: 331-340.

Venable, D.L., Burquez, A.M., Corral, G., Morales, E. \& Espinosa, F. 1987. The ecology of seed heteromorphism in Heterosperma pinnatum in Central Mexico. Ecology 68: 65-76.

Verdú, M. \& Traveset, A. 2005. Early emergence enhances plant fitness: A phylogenetically controlled meta-analysis. Ecology 86: 1385-1394.

Violle, C., Castro, H., Richarte, J. \& Navas, M.L. 2009. Intraspecific seed trait variations and competition: Passive or adaptive response. Functional Ecology 23: 612-620.

Wang, Y.J., Shi, X.P. \& Zhong,Z.C. 2013. The relative importance of sexual reproduction and clonal propagation in rhizomatous herb Iris japonica Thunb. from two habitats of Jinyun Mountain, Southwest China. Russian Journal of Ecology 44: 199-206.
Wang, Y.J., Shi, X.P., Peng, Y., Zhong, Z.C. \& Tao, J.P. 2012. Effects of fine-scale pattern of dwarf bamboo on understory species diversity in Abies faxoniana forest, southwest China. Sains Malaysiana 41: 649-657.

Wang, Y.J., Tao, J.P. \& Zhong, Z.C. 2009. Factors influencing the distribution and growth of dwarf bamboo, Fargesia nitida, in a subalpine forest in Wolong nature Reserve, southwest China. Ecological Research 24: 1013-1021.

Weiner, J., Martinez, S., Müller-Schärer, H., Stoll, P. \& Schmid, B. 1997. How important are environmental maternal effects in plants? A study with Centaurea maculosa. Journal of Ecology 85: 133-142.

Westoby, M.,Falster, D.S., Moles, A.T., Vesk,P.A. \& Wright, I.J. 2002. Plant ecological strategies: Some leading dimensions of variation between species. Annual Review of Ecology and Systematics 33: 125-159.

Zhang, J. \& Maun, M. 1990. Seed size variation and its effects on seedling growth in Agropyron psammophelum. Botanical Gazette 151: 106-113.

College of Horticulture \& Forestry Sciences

Huazhong Agricultural University

Wuhan 430070

China

*Corresponding author; email: wangyj@mail.hzau.edu.cn

Received: 25 February 2014

Accepted: 30 September 2014 